\title{
STIGMA TERHADAP ORANG POSITIF COVID-19
}

\section{Stigma Against Positive People Covid-19}

\author{
Ramly Abudi ${ }^{1}$, Yasir Mokodompis ${ }^{2}$ Allika Nurfadias Magulili ${ }^{3}$ \\ ${ }^{1,23}$ Universitas Negeri Gorontalo, Gorontalo \\ e-mail: allikanurfadias@gmail.com
}

\begin{abstract}
Abstrak
Coronavirus $(\mathrm{CoV})$ adalah virus yang menginfeksi sistem pernapasan. Infeksi covid 19 di Indonesia pertama kali dilaporkan sebanyak 2 kasus pada tanggal 2 maret 2020. Masalah lain yang muncul ditengah masyarakat adalah adanya stigma dan diskriminasi terhadap penderita dan keluarga. Banyak pasien memang sulit untuk mengungkap riwayatnya karena stigma terhadap pasien COVID-19 dan kondisi sosial masyarakat.

Selain menyembunyikan keadaan sebenarnya, keluarga pasien justru marah ketika ditanyai mengenai riwayat kontak. Salah satu penyebabnya adalah arus informasi mengenai virus corona yang sangat masif. Ini disebabkan karena kurangnya informasi mengenai kesehatan khususnya tentang covid 19 di tengah masyarakat Informasi terkait COVID-19 terdapat 4 kategori pasien yang dapat membantu tenaga kesehatan terutama tenaga medis dan pihak pemerintah dalam mengetahui atau menganalisis pasien yaitu diantaranya : Orang Dalam Pemantauan (ODP), Pasien Dalam Pengawasan (PDP) atau suspek, Orang Tanpa Gejala (OTG), dan positif COVID-19. Beberapa cara telah dilakukan pemerintah dalam mengurangi penyebaran virus korona.

Setelah resmi dideklarasikan sebagai pandemik global, WHO segera memberikan 30 pesan yang dikelompokkan menjadi 6 (enam) grup pesan terkait COVID-19. Penyebab kesembuhan pasien salah satunya dengan memeberikan informasi yang baik. Menghindari stigma pada pasien postif, bila perlu membantu apabila ada ODP di wilayah kita, yang kiranya harus karantina mandiri, harus saling support demi kesembuhannya.
\end{abstract}

Kata kunci: Informasi; Positif Covid-19; Stigma

\section{Abstract}

The emergence of a global pandemic COVID-19 caused a negative stigma for patients and their families. Stigma is a term that describes a situation or condition related to the perspective of something that is considered negative. Usually stigma is at the burden of disease. Stigma in the context of health is a negative relationship between a person or group of people who share certain characteristics and certain diseases. Many patients find it difficult to reveal their history because of the stigma of COVID-19 patients and the social conditions of the community. Not only lying, the patient's family actually angry when asked about the contact history.

One reason they lie is the massive flow of information about the corona virus. This is closely related to the lack of health literacy, where people are not accustomed to dealing with balanced data. To help the government and health authorities analyze their patients, there are at least 4 people related to COVID-19, namely: People in Monitoring (ODP), Patients in Oversight (PDP) or suspects, People without symptoms (OTG), and positive COVID- 19 The government has made efforts to reduce the spread of COVID-19 in several ways. After being officially declared a global pandemic, WHO immediately gave 30 messages grouped into 6 (six) message groups related to COVID-19.

Good news or information is one of the supporting factors of healing. If there is something positive, don't be stigmatized. If necessary, help if there is an ODP in our area, which must be an independent quarantine, must support each other for healing.

Keywords: Information; Positive Covid-19; Stigma

(C) 2020- Ramly Abudi, Yasir Mokodompis, Allika Nurfadias Magulili Under the license CC BY-SA 4.0 


\section{PENDAHULUAN}

Dunia telah memasuki era globalisasi dengan berbagai aspek terkait di dalamnya. Teknologi Informasi (TI) menjadi salah satu aspek globalisasi di bidang teknologi terkini. Dengan TI, penyampaian data dan pengolahan informasi menjadi sangat cepat, akurat, dan dapat menjangkau seluruh pelosok negara. Selain banyak memiliki sisi positif, berita hoax banyak menyebar di media sosial. ${ }^{1}$

Menghadapi wabah virus corona, Indonesia saat ini mengalami beban ganda dalam masalah penyakit (Double burden disease \} masalah penyakit menular khusunya penyakit yang berbasis lingkungan seperti diare, malaria, demam berdarah $\{\mathrm{DBD}\}$ dan TBC. Pada saat yang sama penyakit-penyakit degeneratif juga mengalami peningkatan kasus yang sangat tinggi seperti hipertensi, penyakjit jantung, diabetes mellitus dan penyakit stroke. Kondisi ini akan menperberat penanggulangan penyakit covid 19 apabila yang terinfeksi adalah orang yang menderita penyakit degeneratif. ${ }^{12,13}$

Terdapat 2 kasus wabah yang terjadi di dalam 2 dekade awal di abad ini. diantaranya : pertama kasus yang terjadi pada tahun 2002 di Guangdong, China yaitu Severe Acute Respiratory Syndrome (SARS) yang disebabkan oleh SARS Coronavirus (SARS-CoV) Kedua, terjadi pada tahun 2012 di Arab Saudi yaitu Middle Eastern Respiratory Syndrom (MERS) Coronavirus (MERS-CoV). Ketiga, terjadi pada tahun 2019 di Wuhan, Hubei China yaitu Coronavirus Disease 2019 (Covid-19) yang disebabkan oleh SARS Coronavirus 2 (SARSCoV-2). Penyakit ini terjadi pada akhir 2019 dan awal 2020. ${ }^{3}$,

Awalnya virus tersebut. Di kota Wuhan terdapat suatu pasar grosir makanan Laut Huanan yang ramai memberitakan virus tersebut. Awalnya virus ini dikenal dengan 2019 novel coronavirus atau 2019-nCoV. Pada tanggal 11 Februari 2020. WHO meresmikan penyakit ini dengan istilah COVID-19. Untuk
Coronavirus Disease 2019 yang disingkat menjadi COVID-19. Penyakit ini sama seperti influenza yang disebabkan oleh SARS-CoV-2 atau severe Acute Respiratory Syndrome Coronavirus 2. Tanda dan gejala penyakit ini antara lain demam, batuk, sakit kepala, batuk, dan ada beberapa yang memiliki riwayat penyakit lainnya seperti saluran pernafasan bawah, walaupun virus ini pada umumnya sering dikaitkan dengan saluran pernapasan bagian atas. ${ }^{10,2}$

Pada tanggal 2 maret 2020 terdapat 2 kasus COVID-19 di Indonesia dan dilaporkan pertama kali. Terdapat 6.760 kasus konfirmasi, 590 kasus meninggal (8,7\%), 747 kasus sembuh $(11,1 \%) 5.423$ kasus dalam perawatan $(80,2 \%)$ tercatat hingga tanggal 20 April 2020 pukul 16.30 WIB. Kasus ini membuat aktivitas lama yang merupakan kebiasaan berubah menjadi aktivitas baru. Pembelajaran di dunia pendidikan berubah menjadi sistem e-learning and blended lerning, dengan menggunakan pembelajaran online. ${ }^{7}$

Banyaknya informasi yang tidak dapat dipercaya dari sosial media yang telah menimbulkan stigma pada penderita COVID-19, yang kita tahu bersama bahwa penyakit ini sangat cepat menular dan belum ada obatnya. Sehingga pada makalah ini akan mengulas bagaimana stigma terhadap orang positif COVID-19 yang ditinjau dari berbagai aspek. ${ }^{8}$

\section{METODE}

Metode yang digunakan adalah data sekunder yaitu data yang didapatkan tidak secara langsung dari objek atau subjek penelitian. Karena dalam makalah ini sumber yang digunakan berupa jurnal ilmiah, artikel dalam sosial media maupun buku.

Berbagai macam sumber tersebut digunakan sebagai tujuan dari pembuatan makalah ini yaitu menjawab segala permasalahan terkait stigma terhadap orang 
postif COVID-19. Data yang dikumpulkan ini dilakukan hanya pada suatu waktu tertentu.

\section{HASIL DAN PEMBAHASAN}

Stigma Penderita COVID-19 Stigma. merupakan Sesuatu yang dianggap bernilai negative terhadap suatu keadaan atu kondisi. Stigma di masyarakat biasanya selalu ditandai dengan melekatnya anggapan negative terhadap seseorang untuk mengetahui krakteristik atau penilaian terhadap orang lain. Biasanya stigma dapat menjadi beban penyakit. ${ }^{12}$

Dalam dunia kesehatan stigma adalah interaksi negative antara satu orang atau kelompok orang dengan orang lain terhdap penykit tertentu dn sifat tertentu. Sebagai contoh penderita COVID-19 di masyarakat memiliki stigma negative di masyarakat. Sehingga orangorang disekitarnya lebih memilih menjauh dan tidak ingin berkontak langsung dengan penderita walaupun sudah dinyatakan positif. Ada konsensus bahwa penelitian stigma mengambil dua jalur oposisi dan terisolasi:

1) Pendekatan mikro-sosial, dicirikan oleh kerja psikologis (sosial), memeriksa stigma di tingkat individu dan antar individu.

2) Pendekatan makro-sosial, dilambangkan dengan karya sosiologis, berkaitan dengan analisis tingkat kelompok (sosial/budaya) dan struktural. ${ }^{11}$

Stigma negative pada penderita Covid19 maupun keluarganya timbul akibat pandemic global pada awal tahun 2020 . COVID19 merupakan penyakit menular dengan proses penularannya sangat cepat dan dapat berakibat pada kematian. Banyak pasien memang sulit untuk mengungkap riwayatnya karena stigma terhadap pasien COVID-19 dan kondisi sosial masyarakat. Untuk saat ini virus COVID-19 belum ada obatnya. ${ }^{5}$

Bahkan pihak keluarga pasien tidak senang jika petugas medis bertanya terkait riwayat kontak. Dalam upaya pencegahan penyebaran Covid-19 dan pentingnya dalam mengidentifikasi pasien, sebagian besar masyarakat memilih menyembunyikan keadaan yang sebenarnya sehingga menyulitkkan tenaga medis dalam menjalankan tugas. Salah satu penyebab mereka berbohong adalah arus informasi mengenai virus corona yang sangat masif. Terdapat 2 jenis informasi yaitu informasi negative dan positif.

Informasi negative memiliki tujuan untuk mendidik masyarakat, tapi ada sebagian orang yang tidak bisa membedakan antara informasi negtif dan positif. Secara psikologis, informasi negatif lebih mudah di serap sehingga membuat orang percaya hal itu menjadi kebenaran. Hal ini berhubungan dengan kurangnya potensi masyarakat dalam mengelola dan memahami informasi terkait dengan kesehatan, sebab data yang tidak seimbang beredar di masyarakat. Dalam dunia kesehatan masyarakat kurang mendapatkan informasi yang sebenarnya.

Masyarakat sudah terbiasa dengan ajaran tentang sebab-akibat jika seseorang terekena penyakit serta dampaknya apa. Ha ini yang menyebabkan timbulnya istilah stigma, dimana stigma adalah kemampuan menyeimbangkan informasi positif dan negative juga kurangnya potensi masyarakat dalam mengelola dan memahami informasi kesehatan, stigma pada pasien covid-19 biasanya akan di jauhi di isolasi dari keluarganya, karena akan ada pertanyaan pasien akan sembuh atau akan menularkan kepada orang lain yang terjadi di masyarakat yaitu kebaikan dari help seeking (mencari pertolongan), dengan kata lain seharusnya pasien mencari pertolongan ke fasiitas kesehatan. Hal ini di tandai dengan penolakkan dari masyarakat, kebohongan, maupun penolakkan terhadap jenazah. Virus ini telah memberikan pengetahuan kepada masyarakat terkait kesehatan dalam waktu yang cepat.

Virus ini juga pertama kali muncul dan saat ini berkembang dengan pesat. Jika 
seseorang memiliki daya tahan imun yang kuat virus ini tidak akan mudah menyerang tubuh Dengan melakukan test tertentu, akan diketahui apakah seseorang terinfeksi atu tidak. Dalam menganalisis para psien Covid-19 dikategorikan menjdi 4 istilah yaitu orng dlam pemantauan(ODP), Pasien dalam pengawasan (PDP) atau suspek, orang tanpa gejala (OTG), dan positif Covid-19. Gejala yang dimiliki oleh Orang Dalam Pemantauan yaitu yang memenuhi criteria sebagai berikut : demam pada suhu: $38^{\circ} \mathrm{C}$ atau demam, batuk atau pilek, memiliki riwayat perjalanan ke negara yang memiliki transmisi lokal COVID-19, tinggal selama 14 hari terakhir di daerah dengan trnsmisi lokal di Indonesia.

Yang dikategorikan sebagai suspek atau Pasien dalam pengawasan (PDP) merupakan Seseorang yang memiliki gejala: demam, atau demam akibat dari: batuk/pilek/sesak napas tidak disertai pneumonia, dan mempunyai riwayat perjalanan ke wilayah yang memiliki transmisi lokal COVID-19 dalam 14 hari terakhir sebeum adanya gejala atau pernah berkontak langsung dengan pasien positive COVID-19. Orang Tanpa Gejala (OTG) adalah orang-orang yang tidak memiliki gejala tetapi memiliki risiko tertular dri yang terkonfirmasi postif Covid-19.

Kategori Orang Tanpa Gejala (OTG) mempunyai riwayat kontak dengan penderita, apakah itu kontak langsung atau dalam ruangan yang sama dengan pasien Covid-19 dengan radius 1 meter. Serta kelompok yang paling di takuti adalah postif Covid-19 atau disebut juga "kasus konfirmasi". Dalam kondisi ini seseorang terbukti sudah terinfeksi virus Covid-19 berdasarkan hasil laboratorium. Diagnosis COVID-19 harus dikonfirmasikan dengan reverse transcription polymerase chain reaction (RT-PCR) atau sekuensing gen untuk spesimen pernapasan atau darah, sebagai indikator kunci untuk rawat inap. ${ }^{4}$
Selanjutnya dilakukan CT scan dada yang memiliki sensitivitas yang lebih tinggi untuk diagnosis COVID-19 dibandingkan dengan RT-PCR dari sampel swab di daerah epidemi Cina. Perlu pula diketahui juga bahwa istilah COVID-19 merujuk ke penyakit yang diderita oleh pasiennya. Sedangkan SARS-CoV2 merupakan virus yang menyebabkan penyakit COVID-19 tersebut. Informasi COVID-19 dari Media Sosial dan Online Perkembangan TI yang pesat membuat pergeseran media komunikasi dan interaksi menjadi bentuk baru berupa media sosial online lintas platforms. ${ }^{8}$

Dengan adanya media sosial, masyarakat dapat mengakses dan mendapatkan data ataupun informasi dengan mudah. Berita yang berhubungan dengan covid-19 menjadi informasi yang menjadi trending setiap hari terhitung sejak adanya kasus pandemi ini. dari sosial media juga beredar terjadi penolakkan pemakaman jenazah COVID-19. Hal ini bukan saja terjadi dimasyarakat tetapi tenaga medis yang menangani pasien juga mendapatkan perlakuan yang sama dari masyarakat Upaya pemerintah dalam menekan penyebarn virus COVID-19 ada beberapa cara yaitu 1) dengan membentuk gugus tugas penanganan COVID-19 berdasarkan Kepres Nomor 7 tahun 2020,

2) Penerapan PSBB disejumlah Provinsi Kabupaten Kota yang memiliki pasien Covid 3 \} Menganjurkan pola hidup sehat, pemakaian masker kain, mencuci tangan menggunakan sabun. ${ }^{9}$

Penyakit ini dikatakan pandemic sebab penyakit ini bersifat menulr dan telh menyebr ke bnyak wilayah beberapa Negara. Pandemi global COVID-19 sendiri sampai dengan tanggal 20 April 2020 telah menyebar ke 213 negara/teritorial. Secara global, sampai dengan pukul 01:00 PM, 20 April 2020, ada 2.285.210 kasus COVID-19 yang dikonfirmasi, termasuk 155.124 kematian $(6,79 \%)$, dilaporkan kepada WHO. ${ }^{6}$ 
Vol. 2, No 2 (2020) : Juli

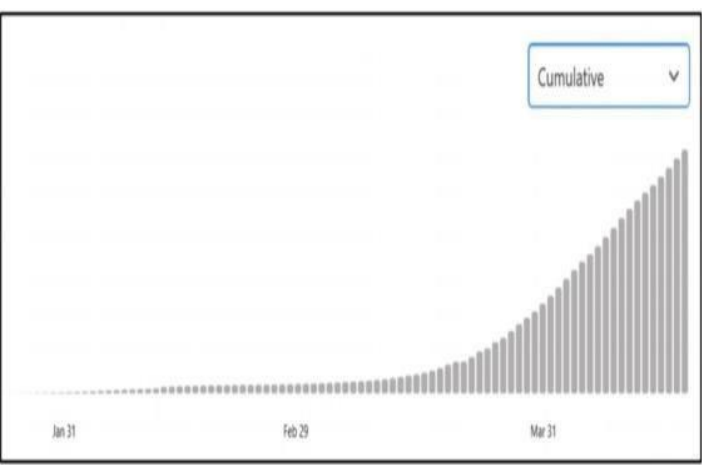

Gambar 1. Statistik Kumulatif Global Kasus COVID-19 (20 April 2020)

Berdasarkan data dari badan kesehatan dunia $\{\mathrm{WHO}\}$ melaporkan bahwa terdapat 12 (dua belas) negara yang memiliki jumlah kasus COVID-19 tertinggi di dunia. Pada awal pandemi, China merupakan negara tempat dimana pertama kali virus ditemukan, namun justru jumlah kasus tertinggi di dunia justru terdapat di united states of America (USA) hingga periode pelaporan sampai pada awal april 2020, hingga saat ini sebagian besar negara di benua eropa dan amerika telah melaporkan adanya kasus dan terus mengalami peningkatan. ${ }^{7}$

Tabel 1. Top 12 countries, areas or territories with cases of COVID-19 per 20 April 2020

\begin{tabular}{|c|c|c|c|}
\hline No & Country & Continent & Cases \\
\hline 1. & $\begin{array}{l}\text { United } \\
\text { States of } \\
\text { America }\end{array}$ & America & 723.605 \\
\hline 2. & Spain & Europe & 191.726 \\
\hline 3. & Italy & Europe & 175.925 \\
\hline 4. & Germany & Europe & 139.897 \\
\hline 5. & $\begin{array}{l}\text { The } \\
\text { United } \\
\text { Kingdom }\end{array}$ & Europe & 114.221 \\
\hline 6. & France & Europe & 110.721 \\
\hline 7. & China & Asia & 84.237 \\
\hline 8. & Turkey & Europe/Asia & 82.329 \\
\hline 9. & $\begin{array}{l}\text { Iran } \\
\text { (Islamic }\end{array}$ & Asia & 82.211 \\
\hline
\end{tabular}

\begin{tabular}{llll}
\hline & $\begin{array}{l}\text { Republic } \\
\text { of) }\end{array}$ & & \\
\hline 10. & $\begin{array}{l}\text { Russian } \\
\text { Federation }\end{array}$ & Europe/Asia & 42.853 \\
\hline 11. & Belgium & Europe & 37.183 \\
\hline 12. & Brazil & America & 36.599 \\
\hline
\end{tabular}

COVID-19, di Indonesia dilaporkan pertama kali pada tanggal 2 Maret 2020 sejumlah dua kasus. Pada tanggal 20 April 2020 Pukul 16.30 WIB (Infeksi Emerging Kemkes RI, 2020) update jumlah kasus di Indonesia adalah 6.760 Kasus Konfirmasi, 590 Kasus Meninggal (8,7\%), 747 Kasus Sembuh (11,1\%), 5.423 Kasus Dalam Perawatan (80,2\%). Kasus ini membuat aktivitas lama yang merupakan kebiasaan berubah menjadi aktivitas baru. ${ }^{7}$

Pembelajaran di dunia pendidikan berubah menjadi sistem e-learning and blended lerning, dengan menggunakan pembelajaran online. Setelah resmi dideklarasikan sebagai pandemik global, WHO segera memberikan 30 pesan yang dikelompokkan menjadi 6 (enam) grup pesan terkait COVID-19. Ke-enam grup pesan tersebut ditujukan untuk: 1) Populasi umum, 2) Petugas kesehatan, 3) Pemimpin tim atau manajer di fasilitas kesehatan, 4) Pengasuh anak, 5) Orang dewasa yang lebih tua, orangorang dengan kondisi kesehatan yang mendasari dan pengasuh mereka, 6) Orang yang terisolasi. ${ }^{2}$

Selanjutnya, WHO bekerjasama dengan United Nations Children's Fund (UNICEF), International Federation of Red Cross and Red Crescent Societies (IFRC) telah mengeluarkan "Social Stigma associated with COVID-19: A guide to preventing and addressing" (WHO, 2020d). Tingkat stigma yang berkaitan dengan COVID-19 yang berkaitan dengan COVID-19 didasarkan pada tiga faktor utama: 1) Itu adalah penyakit yang baru dan yang masih banyak yang tidak diketahui; 2) Kita sering takut pada yang tidak diketahui; dan 3) Mudah untuk mengaitkan rasa takut itu dengan "orang lain”. Dengan 
dikeluarkannya panduan tersebut dapat dijadikan pedoman bagi pemerintah, media, dan organisasi lokal yang menangani penyakit coronavirus baru (COVID-19). ${ }^{6}$

Berikut adalah beberapa contoh dan kiat tentang tindakan yang mungkin dilakukan untuk melawan sikap stigmatisasi terhadap penderita HIV/AIDS yang dapat diadobsi dalam menanggulangi masalah covid 19: 1) Menyebarkan fakta (Spreading the facts), 2) Melibatkan influencer sosial (Engaging social influencers), 3) Memperkuat suara (Amplify the voices) orang-orang yang pulih 4) Pastikan Anda menggambarkan berbagai kelompok etnis yang menunjukkan beragam komunitas yang terdampak dan bekerja sama untuk mencegah penyakit ini, 5) Jurnalisme etis dengan memromosikan konten seputar praktik pencegahan 6) Tautkan (Link up) sejumlah inisiatif mengatasi stigma dan stereotip untuk menciptakan gerakan dan lingkungan positif yang menunjukkan kepedulian dan empati ${ }^{11}$.

Stop Stigma Terhadap Pasien COVID-

19 Masyarakat diharapkan tetp tenang dalam menghadapi terhadap pandemi Covid-19. Apalagi sampai mengucilkan pasien yang dikategorikan sebagai orang dalam pemantuan (ODP) dan pasien dalam pengawasan (PDP).

Dukungan keluarga dan masyarakat sangat penting dalam meningkatkan sistem imun tubuh pada pasien covid-19. Salah satu penyebab kesembuhan pada pasien postif covid19 dengan memberikan informasi atau kabar baik . Tingkatkan kasih sayang serta saling menyayangi. Jika ada yang positif, jangan di stigma, bila perlu membantu apabila ada ODP di wilayah kita, yang kiranya harus karantina mandiri, memberikan motivasi kepada pasien covid-19 demi kesembuhannya serta melaksanakan protocol kesehatan dalam mencegah agar tidak terjadi penularan. Seperti physical distancing, selalu memakai masker saat berpergian ke luar rumah, serta menerapkan perilaku hidup bersih dan sehat ${ }^{5}$

\section{KESIMPULAN}

COVID-19 merupakan suatu penyakit yang disebabkan oleh SARS Coronavirus 2 (SARS- CoV-2). Pemberian nama penyakit dilakukan oleh WHO, sedangkan pemberian nama virus oleh International Committee on Taxonomy of Viruses (ICTV). COVID-19 merupakan penyakit menular yang dapat dengan cepat dan mudah menyebar antar manusia. COVID-19 hingga saat ini belum ditemukan vaksin, upaya pencegahan dapat dilakukan dengan sistem imun tubuh manusia yang kuat dan sehat. Orang yang terinfeksi virus COVID19 bukan disebabkan karena perilaku yang berkaitan dengan aib, sehingga tidak perlu dikucilkan apalagi dijauhi. Masyarakat diharapkan tidak panik dalam menaggapi pandemi COVID-19.

Stigma negatif kepada para penderita positif COVID-19 haruslah dianulir dengan literasi kesehatan yang optimal dari berbagai pihak. Dukungan semua pihak agar penderita COVID-19 bisa semangat untuk sembuh sangatlah diharapkan. Peranan pemerintah, praktisi kesehatan, dan tokoh masyarakat dalam memberikan edukasi terkait COVID-19 akan sangat membantu agar masyarakat tidak melekatkan stigma negatif kepada orang terkait COVID-19. Walaupun tidak termasuk ke penderita COVID-19, namun harus tetap memperhatikan pola hidup sehat (konsumsi vitamin $\mathrm{C}$ dan $\mathrm{E}$ ), menjaga kebersihan, cuci tangan pakai sabun, menggunakan masker kain jika perlu, menjaga imunitas tubuh, berjemur setiap hari, menjaga social distancing/physical distancing, memperhatikan anjuran WHO, pemerintah, kemenkes, dan sebagainya. 


\section{UCAPAN TERIMA KASIH}

Dengan terselesaikannya penyusunan tugas ini, saya sebagai penyusun mengucapkan terima kasih yang sedalam-dalamnya kepada Allah SWT. atas limpahan karunia dan hidayahnya sehingga saya dapat menyelesaikan penelitian ini. serta tak lupa pula saya mengucapkan terima kasih kepada semua pihak yang telah mendukung saya atas terselesaikannya artikel ini.

\section{DAFTAR PUSTAKA}

[1] Abdillah, L. A. Analisis Aplikasi Mobile Transportasi Online Menggunakan User Experience Questionnaire pada Era Milenial dan Z. JSINBIS (Jurnal Sistem Informasi Bisnis), 2019; 9(2), pp. 204211. doi: 10.21456/vol9iss2pp204-211.

[2] Peiris, J. S. M. et al. Coronavirus as a Possible Cause of Severe Acute Respiratory Syndrome. Lancet, 2003; 361(9366), pp. 1319-1325. doi: 10.1016/S0140-6736(03) 13077-2.

[3] WHO. (2020). Naming The Coronavirus Disease (COVID-19) and The Virus That Causes it. [Diakses pada tanggal 9 Mei 2020]. Available at:https://www.who.int/emergencies/disea s /novel-coronavirus-2019/technical guidance/naming-the-coronavirus disease(covid-2019)-and-the-virus-that-causes-it

[4] Lin, L. et al. Hypothesis for Potential Pathogenesis of SARS-CoV-2 Infectiona review of immune changes in patients with viral pneumonia. Emerging Microbes and Infections. 2020; doi: 10.1080/22221751.2020.1746199.

[5] Susilo, A. et al. Coronavirus Disease 2019 : Tinjauan Literatur Terkini Coronavirus Disease 2019 : Review of Current Literatures. Jurnal Penyakit Dalam Indonesia, 2020; 7(1), pp. 45- 67.

[6] WHO. (2020). Social Stigma Associated With COVID-19: A Guide to Preventing and Addressing. [Diakses pada tanggal 9
Mei 2020]. Available at: http://www.who.int/docs/defaultsource/coronaviruse/covid19-stigmaguide.pdf.

[7] Kompas.com. (2020). Mengapa Pasien Covid-19 Kerap Menyangkal dan Berbohong. [Diakses pada tanggal 9 Mei 2020]. Available at:https://www.kompas.com/sains/read/20 20/04/23/170200923/mengapa-pasiencovid-19- kerap-menyangkal-danberbohong-?page $=1$

[8] Ai, T., Yang, Z. and Xia, L. Correlation of Chest CT and RT-PCR Testing in Coronavirus Disease. Radiology, 2020; 2019, pp. 1-8. doi: 10.14358/PERS.80.2.000.

[9] Keppres No. 7 Tahun 2020. Keputusan Presiden Republik Indonesia No. 7 Tahun 2020 Tentang Gugus Tugas Percepatan Penanganan Corona Virus Disease 2019 (COVID-19). Indonesia.

\{10\}Mutiara Patricia Ladimo, Irwan Irwan MERS-CoV (Middle East Respiratory Syndrome-Corona Virus) menggegerkan dunia timur. Journal Health and Sciens : Gorontalo Journal Health \& Sciens Community, Vol. 4 No.1 2020.

DOI : $10.35971 /$ gojhes http://ejurnal.ung.ac.id/index.php/gojhe s/article/view/4666

\{11\}. Irwan, $\{2017\}$ The model of Risk Behavior at the rise of HIV and AIDS in Adolescent in Gorontalo Province. International Journal of Pharmacy \& Pharmaceutical Research Volume 9 issue 3 June 2017, ISSN : 2349-7203 http://ijppr.humanjournals.com/201 7/ 06/ DOI : 10.25166

\{12\} Dian Saraswaty, Asep Suryana Abdurrahmat, Siti Novianti (2018) : Hubungan Dukungan Sosial Keluarga Dan Pengetahuan Dengan Perilaku Pengendalian Hipertensi Di Wilayah 
Vol. 2, No 2 (2020) : Juli

Kerja Puskesmas Karangnunggal

Kabupaten Tasikmalaya. Journal Health

and Sciens : Gorontalo Journal Health \&

Sciens Community, Vol. 2 No.2 2018

DOI: https://doi.org/10.35971/gojhes.v2i2.527

$\underline{2}$

\{13\}.Irwan. (2018) ; Model of Hypertension

Transmission Risks to Communities in

Gorontalo Province. Indian Journalof

Public Health Research \&

Development Volume 9 Nomor 1

Januari 2018 ISSN : 0976-0245 \{print

0976-5506 (Electronic)

http://www.indianjournals.com/lJOR

A

SPX?target=ijor:ijphrd\&volume=9\&i

ssu $\mathrm{e}=1$ \&article $=058$

DOI :10-5958/0976

5506.2018.00058.X 